\title{
Acta
Biochimica
Polonica
}

Vol. 52 No. 1/2005

$233-241$

QUARTERLY

\section{Light conditions alter accumulation of long chain polyprenols in leaves of trees and shrubs throughout the vegetation season $^{*}$}

\author{
Agnieszka Bajda $^{1 凶}$, Tadeusz Chojnacki ${ }^{1}$, Józefina Hertel ${ }^{1}$, Ewa Swiezewska ${ }^{1}$, \\ Jacek Wójcik $^{1}$, Alicja Kaczkowska ${ }^{2}$, Andrzej Marczewski ${ }^{2}$, Tomasz Bojarczuk ${ }^{3}$, \\ Piotr Karolewski ${ }^{3}$ and Jacek Oleksyn ${ }^{3}$ \\ ${ }^{1}$ Institute of Biochemistry and Biophysics, Polish Academy of Sciences, Warszawa, Poland; \\ ${ }^{2}$ Botanical Garden - Center for Biological Diversity Conservation, Polish Academy of Sciences, \\ Warszawa, Poland; ${ }^{3}$ Institute of Dendrology, Polish Academy of Sciences, Kórnik, Poland
}

Received: 17 January, 2005; accepted: 10 March, 2005

Key words: plant polyprenols, SLA

\begin{abstract}
In many plants belonging to angiosperms and gymnosperms the accumulation in leaves of long chain polyprenols and polyprenyl esters during growth in natural habitats depends on the light intensity. The amount of polyprenols in leaves is also positively correlated with the thickness of the leaf blade (SLA, specific leaf area). The polyprenol content of leaves shows seasonal changes with a maximum in autumn and a minimum in early summer with the difference between poorly and well illuminated plants persisting throughout the vegetation season.
\end{abstract}

Following the discovery in the 1960-ies and 70-ies of polyprenol accumulation in leaves of Ficus elastica (Stone et al., 1967) and in several other plant species (Swiezewska et al., 1994), studies on the accumulation of long chain polyprenols in leaves of various species of angiosperms and gymnosperms have been focused on taxon-dependent differences in the content and the type of the polyprenol mixture. The results of the screening of several hundred plant species performed mainly by the "Collection of Polyprenols" group at the Institute of Biochemistry and Biophysics in Warsaw have demontrated that in about

\footnotetext{
This work was partly supported by grant No. PBZ-KBN-110-P04/19 (E.S.) from the State Committee for Scientific Research (KBN, Poland).

${ }^{凶}$ Correspondence to: A. Bajda, Institute of Biochemistry and Biophysics, Polish Academy of Sciences, A. Pawińskiego 5a, 02-106 Warszawa, Poland; e-mail: agnesb@ibb.waw.pl
}

Abbreviations: HPLC, high performance liquid chromatography; SLA, specific leaf area; TLC, thin-layer chromatography. 
$30 \%$ of the plant species studied significant accumulation of these substances was evident especially at the end of the vegetation season in deciduous leaves (Ranjan et al., 2001) and in several year old needles of gymnosperms (Swiezewska et al., 1994). It has been found recently (Roslinska et al., 2002) that distinct differences exist in the level of accumulation of polyprenols between various plants of the same species belonging to Lauraceae and Magnoliaceae. In the case of Lauraceae in a given species represented by two or more plants growing in one area of the Arboretum of the Botanical Institute in Kunming (South East China) distinct differences in the content of polyprenols in leaves were found. In the case of Magnoliaceae the two studied Magnolia tripetala trees from the different distant parts of the Arboretum in the Botanical Garden, PAS (Warsaw-Powsin, Poland) exhibited large differences in the polyprenol content in leaves. We also noticed some variations of polyprenol content in leaves of Sorbus suecica collected in various parts of the city of Warsaw (Chojnacki, unpublished). The above differences did not reflect the age of the plant or the particular part of the season when the leaves were collected. Seasonal changes of the polyprenol content in leaves of various trees have been described (Chojnacki \& Vogtman, 1984; Swiezewska \& Chojnacki, 1996). It was evident that a distinct increase of polyprenol content is observed at the end of the vegetative season (October, November). The decline of the content noted in our studies in autumn did not represent the overall process and could be due to differences between the leaves of early and late senescence (Koike, 1990). In spite of the variation of polyprenol content the polyprenol pattern remained conserved for each species independently of plant growth conditions and time of the season.

Polyisoprenoid alcohols are secondary metabolites and mature leaves of some plants are a rich source of these substances. Their use as important biochemicals has been documented in numerous catalogues and original papers. It seemed to us that the knowledge of the factors affecting their accumulation might be important both for learning about the mechanism of this process and for increasing their availability as biochemicals (Collection of Polyprenols, Institute of Biochemistry and Biophysics in Warsaw, Catalogue 1995).

The effect of light on the accumulation of polyprenols was evident already in our first rather poorly documented observations comparing plants growing in the shade and in well insolated places. In further studies described in the present paper the value of the SLA (specific leaf area) (Gunn et al., 1999; Westbody et al., 2000) was taken as a measure of the intensity of insolation, thus making the presumed insolation factor more accurate. SLA is a fairly good indicator of foliage light conditions in plants (Reich et al., 1997; 2003; Wright et al., 2004).

\section{MATERIALS AND METHODS}

Leaves of plants growing in various conditions of insolation were collected in four different arboreta situated in the central part of Poland, the Kórnik Arboretum, the Powsin Arboretum, the Rogów Arboretum and the Ursynów Park-Arboretum. In each of them two plants of the same size and age, one growing in conditions of high insolation and the other in low insolation were studied. The differences of insolation between the pairs of plants studied varied from 1:5 to 1:10 when measured with a phytophotometr FF01 in clear wheather in June between 1 and 2 p.m. For insolated leaves the light intensity in varied from 1350 to $1500 \mu \mathrm{Em}^{-2} \mathrm{~s}^{-1}$ and for shadowed ones from 100 to 200 . The oldest leaves were taken from the outside part of the canopy and air dried. When required the weight and the area of the fresh leaf were measured and the SLA (weight/area) value was calculated. Dried leaves were powdered in a milling apparatus and the resulting pow- 
der $(50 \mathrm{mg}$ ) was extracted with $2 \mathrm{ml}$ of acetone/hexane $(1: 1, \mathrm{v} / \mathrm{v})$ or the leaves (100-200 $\mathrm{mg}$ ) were homogenized in an UltraTurrax T25 at a top speed with $4 \mathrm{ml}$ of acetone/hexane $(1: 1, \mathrm{v} / \mathrm{v})$.

After standing for $24 \mathrm{~h}$ with occasional shaking the clear supernatants were subjected to thin-layer chromatography (TLC) on Silica gel plates in ethyl acetate/toluene $(1: 9, \mathrm{v} / \mathrm{v})$ and on RP-18 plates in acetone. The extracts were subjected to alkaline hydrolysis (Wellburn et al., 1967) before chromatography. When polyprenol esters were to be analyzed total extract was analyzed by TLC prior to hydrolysis. Spots of lipids were detected with iodine vapor and compared with standard compounds (mixture of polyprenol esters from Ginkgo biloba and free polyprenol alcohols from Magnolia kobus).

All organic solvents and Silica gel TLC plates and RP-18 plates with concentrating zone were from Merck (Darmstadt, Germany).

Estimation of polyprenol content. Semiquantitative determination of polyprenols was performed by visually comparing the size and intensity of a spot observed on adsorption chromatography with that of a known amount of standard substance (Swiezewska \& Chojnacki, 1996). HPLC was used for quantitative determination of free polyprenols similarly as described earlier (Eggens et al., 1983) with the use of appropriate internal standards, tridecaprenol or tetradecaprenol (obtained from the Collection of Polyprenols). A Hypersil-ODS column, $4.6 \times 60 \mathrm{~mm}, 3 \mu \mathrm{m}$ particle size (Knauer) and a dual pump apparatus (Waters Ass., U.S.A.) with a UV detector set at $210 \mathrm{~nm}$ and an integrator were used. For elution, convex gradients were applied from the initial 2-propanol/methanol/water (8:12:1, by vol.) in pump A to $50 \%$ or $80 \%$ hexane/2-propanol $(7: 3, \mathrm{v} / \mathrm{v})$ in pump $\mathrm{B}$ at a flow rate of $1.5 \mathrm{ml} / \mathrm{min}$ as described earlier (Swiezewska et al., 1992).

\section{RESULTS}

A correlation between the intensity of insolation and the content of polyprenols or polyprenyl carboxylic esters is evident in leaves of various angiosperm and gymnosperm plant species. This dependence can be observed throughout the vegetation season starting in May/June an ending in September/November in almost all studied plants. In very young leaves in May or June no polyprenols were found. One can see in Table 1 that accumulation of polyprenols started either slightly earlier or later in the course of vegetation; very early accumulation was observed in Betula alloghanensis, Magnolia kobus, Chenomeles sp. and Franklinia alatamaha in which the top values of the content of polyprenols are noted already in early August. In other plants the highest amounts were noted in September and October. In the majority of plants studied the distinct seasonal increase of the content of polyprenols was observed in the well insolated plants. In leaves of Carpinus betulus growing in shaded conditions a lack of accumulation was observed troughout the vegetation season. In other plants the relation between the accumulation of polyprenols in leaves and the intensity of insolation was also evident. Only in one case, i.e. in leaves of Magnolia acuminata (August) this relation was not observed. This was an exception that we could not omit in this presentation, though it might have been due rather to erroneous sampling of the material. On evaluating the approximate content of polyprenols from the size and intensity of the chromatographic spot only the main spot of a characteristic polyprenol family (e.g., prenol-10, -11 and -12) representing over 95\% of the total amount of polyprenols was taken into account. It should be noted that in some plant species traces of other groups of longer chain polyprenols might have been expected (e.g., prenol-19, -20 and -21) as was the case of 
Table 1. Polyprenols and polyprenyl esters in leaves of plants growing in shaded and in insolated habitats (July-October 2001 and 2002)

\begin{tabular}{|c|c|c|c|c|c|c|c|c|}
\hline \multirow{3}{*}{$\begin{array}{l}\text { Name of plant } \\
\text { and type of } \\
\text { polyprenols }\end{array}$} & \multicolumn{8}{|c|}{ Approximate content (\% dry weight) } \\
\hline & \multicolumn{2}{|l|}{ July } & \multicolumn{2}{|l|}{ August } & \multicolumn{2}{|c|}{ September } & \multicolumn{2}{|l|}{ October } \\
\hline & 1 & $\mathrm{n}$ & 1 & $\mathrm{n}$ & 1 & $\mathrm{n}$ & 1 & $\mathrm{n}$ \\
\hline \multicolumn{9}{|l|}{ Free polyprenols } \\
\hline $\begin{array}{l}\text { Betula } \\
\text { alleghaniensis }\end{array}$ & $\begin{array}{l}0.2-0.4 \\
<0.2 \\
0.2-0.4 \\
0.4-1.0\end{array}$ & $\begin{array}{l}<0.2 \\
<0.2 \\
<0.2 \\
<0.2\end{array}$ & $\begin{array}{l}1.0-2.0 \\
2.0-4.0\end{array}$ & $\begin{array}{l}0.4-1.0 \\
0.4-1.0\end{array}$ & $\begin{array}{l}2.0-4.0 \\
>4.0\end{array}$ & $\begin{array}{l}1.0-2.0 \\
1.0-2.0\end{array}$ & $\begin{array}{l}2.0-4.0 \\
>4.0\end{array}$ & $\begin{array}{l}1.0-2.0 \\
1.0-2.0\end{array}$ \\
\hline Carpinus betulus & $\begin{array}{l}0.4-1.0 \\
<0.2 \\
0.4-1.0 \\
0.2-0.4 \\
0.4-1.0 \\
0.4-1.0\end{array}$ & $\begin{array}{l}<0.2 \\
<0.2 \\
<0.2 \\
<0.2 \\
<0.2 \\
<0.2\end{array}$ & $\begin{array}{l}1.0-2.0 \\
0.4-1.0 \\
1.0-2.0\end{array}$ & $\begin{array}{l}<0.2 \\
<0.2 \\
<0.2\end{array}$ & $\begin{array}{l}2.0-4.0 \\
2.0-4.0 \\
2.0-4.0\end{array}$ & $\begin{array}{l}0.4-1.0 \\
<0.2 \\
<0.2\end{array}$ & $\begin{array}{l}2.0-4.0 \\
1.0-2.0 \\
2.0-4.0\end{array}$ & $\begin{array}{l}<0.2 \\
<0.2 \\
<0.2\end{array}$ \\
\hline Carya ovata & & & $0.4-1.0$ & $<0.2$ & $0.4-1.0$ & $<0.2$ & $0.4-1.0$ & $0.2-0.4$ \\
\hline $\begin{array}{l}\text { Liriodendron } \\
\text { tulipifera }\end{array}$ & & & $0.2-0.4$ & $<0.2$ & & & & \\
\hline $\begin{array}{l}\text { Magnolia } \\
\text { acuminata }\end{array}$ & & & $0.2-0.4$ & $0.2-0.4$ & & & & \\
\hline Magnolia kobus & $\begin{array}{l}<0.2 \\
0.2 \\
0.2-0.4\end{array}$ & $\begin{array}{l}<0.2 \\
<0.2 \\
<0.2\end{array}$ & $\begin{array}{l}2.0-4.0 \\
1.0-2.0\end{array}$ & $\begin{array}{l}<0.2 \\
<0.2\end{array}$ & $\begin{array}{l}1.0-2.0 \\
2.0-4.0\end{array}$ & $\begin{array}{l}<0.2 \\
<0.2\end{array}$ & $\begin{array}{l}2.0-4.0 \\
2.0-4.0\end{array}$ & $\begin{array}{l}0.2-0.4 \\
1.0-2.0\end{array}$ \\
\hline Magnolia tripetala & $\begin{array}{l}<0.2 \\
<0.2\end{array}$ & $\begin{array}{l}<0.2 \\
<0.2\end{array}$ & $\begin{array}{l}1.0-2.0 \\
0.4-1.0 \\
1.0-2.0\end{array}$ & $\begin{array}{l}<0.2 \\
<0.2 \\
<0.2\end{array}$ & $\begin{array}{l}2.0-4.0 \\
2.0-4.0 \\
1.0-2.0\end{array}$ & $\begin{array}{l}<0.2 \\
<0.2 \\
<0.2\end{array}$ & $\begin{array}{l}>4.0 \\
2.0-4.0\end{array}$ & $\begin{array}{l}0.4-1.0 \\
<2.0\end{array}$ \\
\hline Tilia cordata & $\begin{array}{l}0.4-1.0 \\
0.4-1.0 \\
1.0-2.0 \\
1.0-2.0\end{array}$ & $\begin{array}{l}<0.2 \\
<0.2 \\
<0.2 \\
<0.2\end{array}$ & $\begin{array}{l}1.0-2.0 \\
1.0-2.0\end{array}$ & $\begin{array}{l}<0.2 \\
<0.2\end{array}$ & $\begin{array}{l}1.0-2.0 \\
1.0-2.0\end{array}$ & $\begin{array}{l}0.4-1.0 \\
0.2-0.4\end{array}$ & $\begin{array}{l}1.0-2.0 \\
2.0-4.0\end{array}$ & $\begin{array}{l}0.4-1.0 \\
1.0-2.0\end{array}$ \\
\hline \multicolumn{9}{|c|}{ Esterified polyprenols } \\
\hline Cornus florida & $<0.2$ & $<0.2$ & $0.2-0.4$ & $<0.2$ & $1.0-2.0$ & $0.4-1.0$ & $1.0-2.0$ & $0.2-0.4$ \\
\hline Chenomeles sp. & $<0.2$ & $<0.2$ & $\begin{array}{l}0.2-0.4 \\
2.0-4.0\end{array}$ & $\begin{array}{l}0.2-0.4 \\
<0.2\end{array}$ & $\begin{array}{l}0.2-0.4 \\
>0.4\end{array}$ & $\begin{array}{l}0.4-1.0 \\
<0.2\end{array}$ & $\begin{array}{l}1.0-2.0 \\
>0.4\end{array}$ & $\begin{array}{l}0.4-1.0 \\
<0.2\end{array}$ \\
\hline $\begin{array}{l}\text { Crataegus } \\
\text { coccinea }\end{array}$ & & & $0.4-1.0$ & $0.2-0.4$ & $1.0-2.0$ & $0.4-1.0$ & $0.4-1.0$ & $0.4-1.0$ \\
\hline Crataegus nigra & & & & & $0.2-0.4$ & $<0.2$ & $0.4-1.0$ & $<0.2$ \\
\hline $\begin{array}{l}\text { Franklinia } \\
\text { alatamaha }\end{array}$ & $\begin{array}{l}1.0-2.0 \\
0.4-0.1 \\
0.2-0.4 \\
0.4-1.0 \\
0.2-0.4 \\
<0.2\end{array}$ & $\begin{array}{l}<0.2 \\
<0.2 \\
<0.2 \\
<0.2 \\
<0.2 \\
<0.2\end{array}$ & $\begin{array}{l}>4.0 \\
2.0-4.0\end{array}$ & $\begin{array}{l}0.2-0.4 \\
0.4-0.1\end{array}$ & $\begin{array}{l}>4.0 \\
>4.0\end{array}$ & $\begin{array}{l}1.0-2.0 \\
0.4-1.0\end{array}$ & $\begin{array}{l}>0.4 \\
>0.4\end{array}$ & $\begin{array}{l}2.0-4.0 \\
1.0-2.0\end{array}$ \\
\hline $\begin{array}{l}\text { Stewartia } \\
\text { pseudocamelia }\end{array}$ & $0.2-0.4$ & $0.2-0.4$ & $0.4-1.0$ & $0.4-1.0$ & $0.4-1.0$ & $0.2-0.4$ & $1.0-2.0$ & $0.2-0.4$ \\
\hline Sorbus intermedia & & & $1.0-2.0$ & $<0.2$ & & & & \\
\hline $\begin{array}{l}\text { Metasequoia } \\
\text { glyptostroboides }\end{array}$ & $0.2-0.4$ & $<0.2$ & $1.0-2.0$ & $1.0-2.0$ & & & $1.0-2.0$ & $0.4-1.0$ \\
\hline Taxus cuspidata & $\begin{array}{l}<0.2 \\
<0.2\end{array}$ & $\begin{array}{l}<0.2 \\
<0.2\end{array}$ & $\begin{array}{l}0.2-0.4 \\
<0.2\end{array}$ & $\begin{array}{l}<0.2 \\
<0.2\end{array}$ & $\begin{array}{l}1.0-2.0 \\
1.0-2.0\end{array}$ & $\begin{array}{l}0.2-0.4 \\
0.2-0.4\end{array}$ & $\begin{array}{l}1.0-2.0 \\
2.0-4.0\end{array}$ & $\begin{array}{l}<0.4 \\
0.2-0.4\end{array}$ \\
\hline
\end{tabular}

l, insolated, light intensity $1350-1500 \mu \mathrm{Em}^{-2} \mathrm{~s}^{-1}$; n, shadowed, light intensity $100-200 \mu \mathrm{Em}^{-2} \mathrm{~s}^{-1}$; the light intensity was measured in July between 1 and 2 p.m. on sunny day with phytophotometer FF01. In all of the plants studied the content of polyprenols in June was below $0.2 \%$. In all plants accumulating free polyprenols the polyprenol family consisted of main prenologues composed of 10-12 isoprene units. In plants accumulating esterified polyprenols the polyprenol family consisted of main prenologues composed of 16-22 isoprene units. Each value represents single plant of different habitat. 
Table 2a. Polyprenol content and specific leaf area in leaves of species accumulating free polyprenols coming from parts of trees exposed to sun light (I) and non-exposed (n) (15 August, 2001)

\begin{tabular}{lll}
\hline $\begin{array}{l}\text { Name of plant and } \\
\text { main prenologues }\end{array}$ & Amount of polyprenols (\% of dry weight) & Specific leaf area $\left(\mathrm{cm}^{2} / \mathrm{g}\right.$ of leaf) \\
\hline $\begin{array}{l}\text { Acer pseudoplatanus } \\
\text { (prenol-11, -12, -13) }\end{array}$ & 0.86 & \\
$\mathrm{l}$ & 0.02 & 101.2 \\
$\mathrm{n}$ & & 385.4 \\
Betula pendula & & \\
(prenol-10, -11, -12) & 0.84 & \\
$\mathrm{l}$ & 0.43 & 141.6 \\
$\mathrm{n}$ & & 168.4 \\
Carpinus betulus & & \\
(prenol-10, -11, -12) & 0.43 & 159.8 \\
$\quad$ & 0.08 & 283.5 \\
$\mathrm{n}$ & & \\
\hline
\end{tabular}

Values are single estimates.

Table 2b. Polyprenol content and specific leaf area in leaves of species accumulating polyprenyl esters coming from parts of trees exposed to sun light (l) and non-exposed (n) (15 September, 2002)

\begin{tabular}{|c|c|c|}
\hline $\begin{array}{l}\text { Name of plant } \\
\text { and main prenologues }\end{array}$ & $\begin{array}{l}\text { Amount of polyprenol esters } \\
\text { (\% of dry weight) }\end{array}$ & $\begin{array}{l}\text { Specific leaf area } \\
\left(\mathrm{cm}^{2} / \mathrm{g} \text { of leaf) }\right.\end{array}$ \\
\hline Ginkgo biloba & & \\
\hline $\begin{array}{l}\mathrm{l} \\
\mathrm{n}\end{array}$ & $\begin{array}{l}1.23 \pm 0.75 \\
0.40 \pm 0.14\end{array}$ & $\begin{array}{r}99.5 \pm 6.4 \\
193.0 \pm 41.0\end{array}$ \\
\hline $\begin{array}{l}\text { Prunus serrula } \\
1 \\
\mathrm{n}\end{array}$ & $\begin{array}{l}1.51 \pm 0.85 \\
0.67 \pm 0.60\end{array}$ & $\begin{array}{l}128.5 \pm 23.3 \\
155.5 \pm 74.2\end{array}$ \\
\hline $\begin{array}{l}\text { Sorbus hybrida } \\
\mathrm{l} \\
\mathrm{n}\end{array}$ & $\begin{array}{l}1.03 \pm 0.43 \\
0.24 \pm 0.12\end{array}$ & $\begin{array}{r}85.5 \pm 10.6 \\
135.5 \pm 17.7\end{array}$ \\
\hline $\begin{array}{l}\text { Sorbus latifolia } \\
\mathrm{l} \\
\mathrm{n}\end{array}$ & $\begin{array}{ll}0.98 & \pm 0.16 \\
0.04 & \pm 0.01\end{array}$ & $\begin{array}{c}93.0 \pm 9.9 \\
205.0 \pm 11.3\end{array}$ \\
\hline
\end{tabular}

Mean values of 3 estimations \pm S.D. are given.

Tilia henryana. In the plants presented in this paper only one polyprenol family was observed, i.e. no additional spot of polyprenols could be detected on thin-layer chromatography apart from the main one.

The seasonal changes of the content of polyprenols in leaves and its dependence on insolation were observed both in angiosperms and gymnosperms. In the case of gymnosperms only two species were studied
(Metasequoia glyptostroboides and Taxus cuspidata) as shown in Table 1 ; in a third studied species, Ginkgo biloba (Table 2b) the effect of insolation was also evident. The rule of season dependent accumulation and the effect of insolation were observed both in the case of non-esterified polyprenols and their esters. The former were of the size $10,11,12$ or 13 isoprene units, the esterified polyprenols were composed of 16-22 isoprene units as 
POLYPRENOL

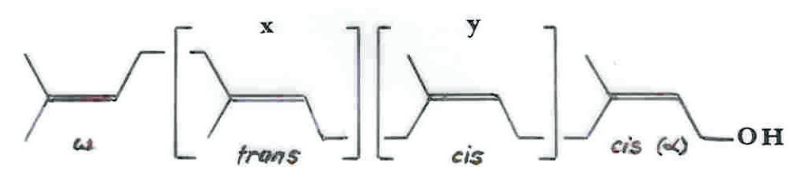

Figure 1. Structure of polyprenols in leaves.

$\omega, \omega$ Isoprene unit; $\mathrm{X}$, internal trans isoprene unit; $\mathrm{Y}$, internal cis-isoprene unit; $\alpha$, terminal cis-isoprene unit. $\mathrm{X}=2, \mathrm{Y}=13-19$ (in polyprenols occurring in the form of carboxylic esters); $\mathrm{X}=3, \mathrm{Y}=6-9$ (in polyprenols occurring in the form of free alcohols).

can be seen in Fig. 2 in which HPLC records of the respective polyprenol families are shown. The typical HPLC records shown in this figure represent the most common polyprenol families encountered in the plant kingdom, i.e. the family od prenol-10, -11, -12 or -13 occuring as free alcohols in leaves of angiosperms and the polyprenol families consisting of prenol-16 or -17 to -22 esterified with carboxylic acid in leaves of representative angiosperm and gymnosperm species. In Fig. 2 polyprenol families from shaded and insolated leaves are shown. In both cases the proportion of individual prenologues is the same. We observed no qualitative differences in the proportions of individual polyprenols in the course of vegetation in any of the plants studied.

\section{A}

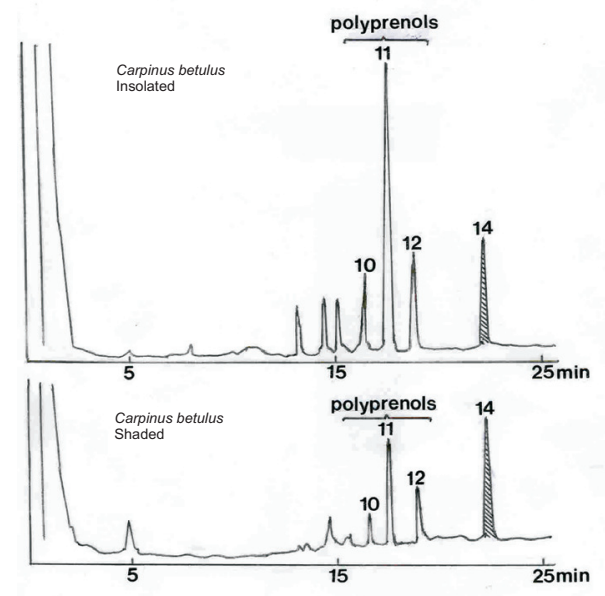

B
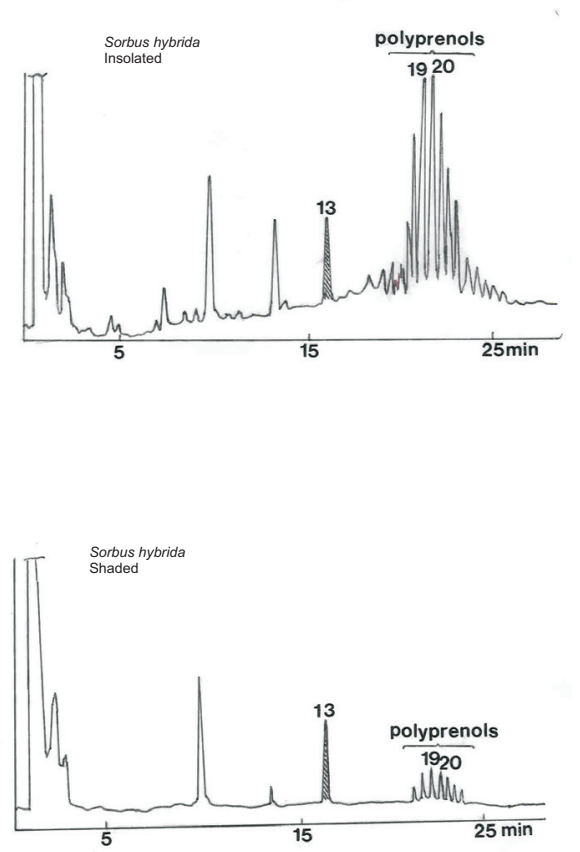

C
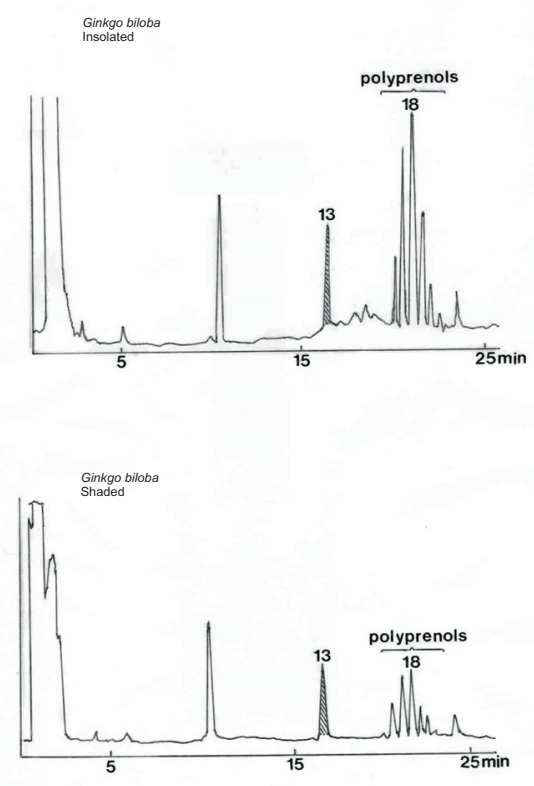

Figure 2. High pressure liquid chromatography of polyprenols isolated from insolated and shaded leaves.

The chromatography was performed as described in Materials and Methods. The internal standards, tridecaprenol (prenol-13) and tetradecaprenol (prenol-14, shadowed) from leaves of Nephelium litchii were used. A. Carpinus betulus (up to $50 \%$ of solution B in the gradient); B. Sorbus hybrida (up to $80 \%$ of solution B in the gradient); C. Ginkgo biloba (up to $80 \%$ of solution B in the gradient). 
Table 2 shows values representing the thickness of the leaves and the content of polyprenols in shaded and insolated leaves. Both values are evidently correlated and they depend on the actual insolation of leaves in natural conditions. In this studies the leaves were taken either from the outer part of the tree well exposed to light or from the inside part in which the leaves were in the shade.

\section{DISCUSSION}

In the studies described in the present paper we wanted to examine the effect of insolation on polyprenol accumulation in photosynthetic tissues both in angiosperms and in gymnosperms and thus to observe the effect of light on polyprenol families of different most common chain length and on free alcohols and their esters. The plant species studied were selected to represent various types of polyprenol families. In the case of gymnosperms perennial plants were not studied to avoid the changes of the accumulation of polyprenols throughout several years of aging which is more complicated (Swiezewska et al., 1994).

The mechanism of the effect of light on the accumulation of polyprenols in leaves has not been solved in this report; the possibility of gene-mediated effect as proposed earlier (Arguello-Astorga \& Herrera-Esterella, 1998) or the result of an overall increase of metabolism or of the formation of ROS (reactive oxygen species) in photochemical reactions might be responsible (Karpinski et al., 1999). The accumulation of polyprenols in leaves is believed to take place in chloroplasts especially at the end of the vegetation season when chromoplasts are evolving from plastids and the insolation dependent rise of polyprenol content could be considered as one of the several physiological phenomena affected by light. A reverse effect of light, a low-light dependent of accumulation of alpha-carotene in needles of spruce was reported (Siefermann-Harms, 1994). In the present paper attention was focused also on the metabolic inequality of leaves of a plant depending on the exposition to sunlight. The thickness of leaves of the outer part of the tree was distinctly greater that in leaves of the inner shaded part. For the plant species studied in this report almost all plants followed the rule according to which the greater the leaf thickness the higher the polyprenol content. Only in one species of Malus the changes of polyprenol content were not accompanied by the change in SLA (not presented in the present paper). Also in the case of Betula pendula and Prunus serrula (Table 2) this dependence was less evident. One should not expect this rule to be strictly obeyed in natural conditions. In all the studied species while the quantity of polyprenols was greatly affected by light the proportions of individual prenologues in the mixture was unchanged. In the case of several species studied in this report the polyprenol content in leaves was quite low in shaded plants (usually $<0.2 \%$ ) and very high (usually up to $4.0 \%$ ) in well insolated leaves. This means that the usefulness of polyprenols as a chemotaxonomic marker should be considered with care as in some plant species growing in shadowed conditions the polyprenols might not accumulated. The present data are in agreement with the early observation (Wellburn \& Hemming, 1966) that in Aesculus hippocastanum the highest accumulation of polyprenols was observed at the end of the vegetation season. Our previous data (Chojnacki \& Vogtman, 1984) showing that in the late autumn we can observe a decrease of the content of polyprenols in leaves did not take into account the fact that the last not fallen leaves remaining on the branches studied by us then were those from the shaded parts of the plant, the thinner ones containing lower amounts of polyprenols.

According to an unpublished observation (Katarzyna Goller) this was the case of a Camelia species (Theaceae family) which was devoid of polyprenols when kept in the green- 
house but turned out to be polyprenol-positive after being kept well insolated in the open air during summer. In our experience several species of Theaceae were known rather as polyprenol-negative. In the present paper we report on the accumulation of a significant amount of polyprenols in Franklinia alatamaha and lower quantities in Stewartia pseudocamelia (Table 1). Studies performed so far on long-term exposure of plants to UV $B$ radiation did not lead to an increase of the amount of polyprenols in leaves (P. Pukacki, unpublished). At present the nature of the observed effect of light on the accumulation of polyprenols in leaves remains obsure. The possibility of light induced activation of the cis-prenyl transferase gene (Arguello-Astorga $\&$ Herrera-Estrella, 1998) is an attractive hypothesis but other pathophysiological mechanisms related to stress should not be excluded (Karpinski et al., 1999).

The results of the present paper demonstrate the inequality of leaves of various parts of a given plant. This inequality is illustrated as great differences of the thickness of the leaves depending on their position on the tree which also reflects insolation and at the same time correlates with the rate of accumulation of polyprenols or polyprenyl esters and perhaps with the function of particular group of leaves as a part of the whole plant organism. Variations of the content of polyprenols in leaves depending on the intensity of insolation of the plant in natural habitat should be taken into account when large scale isolation of polyprenols from leaves is to be made. The phenomenon of accumulation of long chain polyprenols in leaves may be well considered as a result of the light stress-evoked response (Arguello-Astorga \& Herrera-Estrella, 1998; Karpinski et al., 1999).

The kind help of Professor J. Tumiłowicz and Dr. J. Rokosza in selecting and supplying samples of leaves of plants growing in the Rogów Arboretum and in the Nowoursy- nowska Arboretum Park in Warsaw is greatly acknowledged. Professor P. Pukacki of the Institute of Dendrology in Kórnik made measurements of fluorescence the results of which (not shown in this paper) were a useful guide in designing our studies.

\section{R E F E R E N C E S}

Arguello-Astorga G, Herrera-Estrella L. (1998) Evolution of light-regulated plant promoters. Annu Rev Plant Physiol Plant Mol.; 49: 525-55.

Chojnacki T, Vogtman T. (1984) The occurrence and seasonal distribution of 60-polyprenols and C100- and similar long-chain polyprenols in leaves of plants. Acta Biochim Polon.; 31: 115-26.

Eggens I, Chojnacki T, Kenne L, Dallner G. (1983) Separation, quantitation and distribution of dolichol and dolichyl phosphate in rat and human tissues. Biochim Biophys Acta.; 751: $355-69$.

Gunn S, Farrar JF, Collins BE, Nason M. (1999) Specific leaf area in barley: individual leaves versus whole plants New Phytol.; 143: $45-51$.

Karpinski S, Reynolds H, Karpinska B, Wingsle G, Greissen G, Mullineaux P. (1999) The role of hydrogen peroxide and antioxidants in systemic acclimation to photo-oxidative stress. In Arabidopsis Plant Responses to Environmental Stress. Smallwood MF, Calvert CM, Bowles DJ, eds, pp 25-31. BIOS Scientific Publishers Ltd, Oxford, UK.

Koike T. (1990) Autumn coloring, photosynthetic performance and leaf development of deciduous broad-leaved trees in relation to forest succession. Tree Physiol.; 7: 21-32.

Ranjan R, Marczewski A, Chojnacki T, Hertel J, Swiezewska E. (2001) Search for polyprenols in leaves of evergreen and deciduous Ericaceace plants. Acta Biochim Polon.; 48: 579-84.

Reich PB, Walters MB, Ellsworth DS. (1997) From tropics to tundra: global convergence 
in plant functioning. Proc Natl Acad Sci USA.; 94: 13730-4.

Reich PB, Wright, IJ, Cavender-Bares J, Craine JM, Oleksyn J, Westoby M, Walters MB. (2003) The evolution of plant functional variation: traits, spectra, and strategies. Int $J$ Plant Sci.; 164 (3 Suppl): S143-64.

Roślinska M, Walinska K, Swiezewska E, Chojnacki T. (2002) Plant long-chain polyprenols as chemotaxonomic markers. Dendrbiology.; 47: 41-50.

Siefermann-Harms D. (1994) Light dependent changes in the alpha- and beta-carotene content in spruce needles $J$ Plant Physiol.; 143: 488-94.

Stone KJ, Wellburn AR, Hemming FW, Morton RA. (1967) The characterization of ficaprenol-10, -11 and -12 from leaves of Ficus elastica (decorative rubber plant). Biochem J.; 102: 325-30.

Swiezewska E, Chojnacki T. (1996) Polyprenols in leaves of fruit-trees of Rosaceae family. Acta Biochim Polon.; 43: 701-6.

Swiezewska E, Chojnacki T, Jankowski WJ, Singh AK, Olsson J. (1992) The occurrence of long-chain polyprenols in leaves of Rosaceae family and their isolation by time extended liquid chromatography. Biochem Cell Biol.; 70: 448-54.
Swiezewska E, Sasak W, Makowski T, Jankowski W, Vogtman T, Krajewska I, Hertel J, Skopczylas E, Chojnacki T. (1994) The serach for plant polyprenols. Acta Biochim Polon.; 41: 221-60.

Wellburn AR, Hemming FW. (1966) The occurrence and seasonal distribution of higher isoprenoid alcohols in the plant kingdom. Phytochemistry.; 5: 969-75.

Wellburn AR, Stevenson J, Hemming FW, Morton RA. (1967) The characterization and properties of castaprenil-11, -12 and -13 from the leaves of Aesculus hippocastanum (horse chestnut). Biochem J.; 102: 313-24.

Westoby M, Warton D, Reich PB. (2000) The time value of leaf area. American Naturalist.; 155: $640-56$.

Wright IJ, Reich PB, Westoby M, Ackerly DD, Baruch Z, Bongers F, Cavender-Bares J, Chapin FS, Cornelissen JHC, Diemer M, Flexas J, Garnier E, Groom PK, Gulias J, Hikosaka K, Lamont BB, Lee T, Lee W, Lusk C, Midgley JJ, Navas M-L, Niinemets Ü, Oleksyn J, Osada N, Poorter H, Poot P, Prior L, Pyankov VI, Roumet C, Thomas SC, Tjoelker MG, Veneklaas E, Villar R. (2004) The worldwide leaf economics spectrum. $\mathrm{Na}$ ture.; 428: 821-7. 